\title{
Humanistic Value and Management of State-Owned Enterprises in the New Era
}

\author{
Yunfei $\mathrm{Xu}^{1, *}$, Yong Zhang ${ }^{2}$, Yuan Zhang ${ }^{3}$, Dan Wang ${ }^{4}$ \\ 1,2,3,4 State Grid Energy Research Institute Co. LTD, Changping, 102209, Beijing, China \\ *Corresponding author. Email: xuyunfei@sgeri.sgcc.com.cn
}

\begin{abstract}
Humanistic theory provides theoretical guidance and practical reference for comprehensively understanding and exerting the value of "people" and promoting the common development of both the employee and the enterprise. It is of great importance for the high-quality development of state-owned enterprises in the new era. By discussing the development history and connotation extension of humanistic theory, the paper clarified the connotation of humanistic value in Chinese state-owned enterprises in the new era, and further explored the concrete embodiment of humanistic value in state-owned enterprises. On this basis, the paper provided countermeasures and suggestions for strengthening humanistic management of state-owned enterprises in the new Era.
\end{abstract}

\section{Keywords: Humanistic Value, State-Owned Enterprises, Humanistic Management}

\section{INTRODUCTION}

In the new era, the internal and external environment faced by enterprises has undergone important changes. With the rapid development of new technology, economic and social transformation, humanistic management is also facing many new challenges, such as how to deal with the relationship between people and technology. How to deal with the relationship between people and data under the digital background. As the backbone of the national economy, state-owned enterprises have played a vital role in accelerating the transformation of economic development mode. Therefore, state-owned enterprises are expected to play a leading role, perform various reform decisions, and become the main force and pioneer of reform [1]. Based on the new development stage, it is of great theoretical and practical significance to explore the humanistic value of state-owned enterprises in the new era for giving full play to the leading role of state-owned enterprises in reform and development, and promoting the all-round development of people and the high quality development of state-owned enterprises [2].

\section{CONNOTATION OF HUMANISTIC VALUE IN THE NEW ERA}

Under the background of the new era, how should we view the relationship between employees and enterprises? The core to answer this question is how to treat employees. There are two completely different logics for the understanding of employees, namely, economic logic and humanistic logic. Economic logic regards people as a kind of resources, similar as land resources and technical resources, which are the cost items and expenditure items of enterprises. Therefore, once enterprises encountered difficulties in operation, they would consider layoffs to reduce labor costs, or extend working hours, making employees to work overtime endlessly. On the contrary, humanistic logic emphasizes that people are the basis for the survival and development of enterprises, and people always come the first. All the starting points and foothold of enterprises should be centered around "people", and more attention should be paid to people's value [3].

As for the essence of enterprises, Karl Heinrich Marx mentioned the profit-seeking nature of capital primitive accumulation. "When there is a proper profit, capital will be very courageous. If unrest and disputes will bring profits, it will encourage them. Smuggling and slave trade are the evidence. "Peter Drucker considered himself as a "social ecologist" and put forward that enterprises need to be understood from the perspective of human beings. Enterprises are the organs of society, and the market is created by people rather than various economic forces. Therefore, we should perceive and define what kind of goods and services enterprises should provide from the perspective of "people", that is, customers. The essence of an 
enterprise is to solve problems for the society, and a social problem is a business opportunity. The goal of enterprises' survival and development lies not in its economic performance, but in the relationship between people, including the relationship between members of the company and the relationship between external citizens of the company [4].

On August 19, 2019, the CEOs of 181 top American companies jointly signed the Declaration of Corporate Purpose at the Business Roundtable held in Washington. The manifesto redefined the purpose of the company's operation, declaring that the interests of shareholders are no longer the most important goal of a company, and the primary task of the company is to create a better society. In this declaration, CEOs who lead American business, including Jeff Bezos and Tim Cook, collectively proclaimed that a beautiful society is more important than the interests of shareholders. Business leaders stressed that as a company with a sense of social responsibility, the company leadership team are expected to strive to achieve the following goals: to convey corporate value to customers, to invest in employees by hiring different groups and providing fair treatment, to comply with business ethics when dealing with suppliers, to actively participate in social undertakings, to pay attention to sustainable development and create long-term value for shareholders.

In the evolution of great management thoughts, from scientific management theory to behavioral management theory, the emphasis shifts from efficiency improvement to social factors of people. From economic man hypothesis to social man hypothesis, it puts forward the hypothesis of human nature and people's needs. The understanding of management and people is constantly improving and progressing. Whether in academia or practice, the understanding of employees and enterprises eventually returns to the discussion of the relationship between enterprises and people, and pays attention to people's dignity, needs and values [5].

As Karl Heinrich Marx put forward in the Manuscript of Economics and Philosophy in 1884: The all-round development of human beings is "that is to say, as a complete person, people finally possess their own essence." Marx believed that human development mainly includes the development of human labor ability, the development of human social relations, and the development of human free personality. The humanistic principle of management puts forward that "employees are the main body of enterprises and the main body of value creation. Employee participation is the key to effective management. To Make human nature develop perfectly is the core of modern management. To serve people is the fundamental purpose of management.

After the founding of people's republic of China, the people's dominant position has been established. The
Communist Party of China (CPC) insist on taking the people as the center, and put forward the "workers' dominant theory". It is the basic contents and characteristics of humanistic management to respect, rely on, develop and serve people. The theory of worker subject is a theory about the basic characteristics of socialist enterprises put forward by Chinese economist Jiang Yiwei in 1986. According to the theory of worker subject, all workers in an enterprise, including manual workers and mental workers, are all the subject of the enterprise, rather than the object of the enterprise. This is the fundamental difference between socialist enterprises and capitalist enterprises. The theory of employees' subjectivity is one of the main theories embodying the humanistic management theory in China. The core ideas include: "employees are the main body of enterprises, not the object, and importance shall be attached to their positions and roles in business activities. Enterprise management is not only the management of people, but also the management for people, and people should be regarded as the core of management activities. The purpose of business operation is not to simply produce goods, but also to serve the social development of people including employees." The workers' congress and other forms of democratic management system of enterprises and institutions are the concrete embodiment of the peopleoriented management concept. Taking "people" as the main body, "people" include not only the people inside the enterprise who participate in the production and operation activities of the enterprise, but also the users who are closely related outside the enterprise. Therefore, to take effective system design and enterprise management activities to maximize the enthusiasm, initiative and creativity of employees is the concrete embodiment of humanistic management [6].

\section{THE EMBODIMENT OF HUMANISTIC VALUE OF STATE-OWNED ENTERPRISES IN THE NEW ERA}

Under the new era and new situation, state-owned enterprises are faced with complex reform situation such as the reform of state-owned assets and state-owned enterprises, and the reform of power system, which urgently need a profound transformation from thought to action, and fully mobilize and bring into play the enthusiasm and creativity of the broad masses of employees. New technology development, digital transformation and other technological trends and transformation development requirements also need to tackle the following problems about how to achieve technological empowerment, promote technological progress and human progress, and how to enhance people's thinking and skills to achieve digital transformation and development from a human perspective. In this process, entrepreneurs and managers are faced with more challenges. They are expected to 
give full play to their entrepreneurship and be able to take the initiative to reform and forge ahead from a global perspective. At the same time, to promote humanistic management, we need to be aware of the value of people, and attach importance to developing people in leadership and management. It is worth emphasizing that "people" is a broad concept, which includes not only internal members, such as employees, customers, suppliers, government and other external stakeholders, but also a wider range of international and domestic social stakeholders.

In the new era, the humanistic value of state-owned enterprises is embodied in handling "three relations" and undertaking "three responsibilities". Peter Drucker attributed "the concept of company" to "the harmonious relationship between various fields". Companies must fulfill their social obligations automatically in the process of maximizing their own interests. Only when the company itself can contribute to the stability of society and the realization of common goals can the company exist. As Drucker put it, an enterprise is an organ of society and an important part of social ecology. It should integrate itself into the environment and handle the internal and external relations well. As for state-owned enterprises, the foundation of survival and development lies in handling three relationships: first, the relationship between the company and its internal members and employees. The second is the relationship between the company and the government, suppliers, customers and other external stakeholders. Thirdly, the relationship between companies and the society, such as the contribution to international society and global governance in the process of "going out" and "the belt and road initiative".

\section{COUNTERMEASURES AND SUGGESTIONS OF HUMANISTIC MANAGEMENT IN STATE-OWNED ENTERPRISES IN THE NEW ERA}

Based on the new development stage, to gain sustainable competitive advantage in the complex and changeable environment and stimulating market competition, state-owned enterprises need to constantly strengthen the management of employees, especially apply humanistic management, handle the relationship between enterprises and employees, and build a community of employees' interests.

First, to improve the organizational and leadership mechanism. The organizational and leadership mechanism is an important organizational guarantee for state-owned enterprises to practice humanistic management. On the one hand, the SASAC and other state-owned assets management departments need to further optimize the supervision of state-owned assets, guide state-owned enterprises to strengthen humanistic management, and design corresponding inspection indicators in the performance appraisal of the managers of state-owned enterprises to reflect and implement the consideration of employees' well-being. On the other hand, to strengthen the cultivation of humanistic management ability and quality of enterprise leaders. It is very critical to strengthen the study and exchange of humanistic thoughts and practices of managers of stateowned enterprises by strengthening education and training in working methods, ideological style and management skills. The ability and quality of enterprise leaders not only determine the management level of enterprises, but also play an important role in bringing into play the enthusiasm and creativity of employees. Enterprise leaders are required to establish the ideological concept of relying on their employees wholeheartedly, and clearly realize that only relying on the broad masses of employees sincerely can we obtain a steady stream of development momentum. Therefore, enterprise leaders and managers should adhere to the people-oriented ideas and actions, respect and care for employees, handle the relationship with employees, and enhance the sense of ownership and responsibility of employees through enterprise democratic management.

The second is to establish a scientific and standardized management mechanism. A Scientific and standardized management mechanism is the core link of strengthening humanistic management. On the one hand, to establish and improve the incentive mechanisms to arouse the enthusiasm of employees. People-oriented management in modern enterprises, in essence, is to mobilize the enthusiasm of employees through various and multi-level incentive factors or means, so as to promote the development of enterprises. These factors include policy formulation, medium and long-term incentives, emotional input and so on. Through the comprehensive actions of the multi-level incentive mechanisms formed by these factors, the sense of belonging of employees to their enterprise is stimulated, so that the individual behavior of employees is sublimated into the behavior of the enterprise group, and a powerful spiritual power is generated to promote enterprise development. From the perspective of toplevel policy design, enterprises need to formulate policies that are beneficial to arouse the enthusiasm of employees according to the actual situation of enterprises. Emotional incentive is to care about employees' job, study and life, and make them communicate emotionally with enterprises, so as to encourage employees to work harder. Environmental atmosphere incentive is the formation of a public opinion environment conducive to the development of enterprises, such as publicizing, rewarding the advanced, urging the backward, etc., relying on the social function of public opinion to infect and motivate employees subtly. On the other hand, to implement a scientific system to cultivate the quality of employees. This is an important means to develop human resources, 
enhance the enthusiasm and creativity of employees and improve the efficiency of enterprises in people-oriented enterprise management. Specifically, to carry out ideological and political quality education, let them understand the theory of building socialism with Chinese characteristics and the party's major policies, make them understand and abide by socialist professional ethics, and thus strengthening their sense of ownership and responsibility. It is also necessary to carry out vocational education and job training in various forms and at various levels to improve the working skills and enthusiasm of employees. In addition, it is necessary to carry out market economy awareness education, so as to enhance employees' sense of competition and their comprehensive quality to adapt to market changes.

The third is to form a people-oriented modern enterprise management operation mechanism. The corporate governance structure of modern enterprises includes not only the institutional setup of companies, but also the operating rules of these institutions. It is necessary to protect the rights and interests of the owners, give the operators full autonomy in operation, and at the same time arouse the enthusiasm of employees. It is necessary to organically combine the shareholders' meeting, board of directors, board of supervisors and managers of the company to make the enterprise operate orderly, coordinately and efficiently. In addition, we should adhere to the system of democratic election of grass-roots leaders, the system of workers' congress and the system of supervision of employees' suggestions, so as to further improve the operational efficiency of enterprise management institutions and fully mobilize the initiative, enthusiasm and creativity of employees.

Fourthly, to strengthen ties with suppliers, customers and other corporate stakeholders. People-oriented enterprise management includes not only internal subjects such as superior departments and employees, but also external subjects such as suppliers, customers and the community. In the fierce market competition, how to effectively seek, attract and consolidate the relationship with external stakeholders such as suppliers and customers is an important factor related to the survival and development of enterprises. To strengthen the people-oriented enterprise management thought, it is necessary to speed up the process of modern enterprise system construction, further cultivate and improve the market system, and create a relaxed market environment for enterprises to facilitate the full and effective allocation of resources. To establish and perfect the people-oriented enterprise management system is a profound change of the traditional concept of "resources", which is mainly based on material management, and it is also an important measure to establish a modern socialist enterprise management system. By strengthening the people-oriented management mechanism, enterprises are able to better mobilize the enthusiasm, initiative and creativity of employees, enhance their sense of acquisition, happiness and security, and promote the all-round development of employees and the high-quality development of enterprises.

Fifthly, to strengthen the construction of enterprise culture and create a strong cultural atmosphere based on people. By making the strategic objectives, development direction and major initiatives in each period of the enterprise transparent and open, enterprises can publicize to employees in time, arouse the sense of ownership of employees, and enhance their enthusiasm for participating in the development and construction of enterprises. Moreover, to strengthen the promotion of typical experience of enterprises and the study of exemplary spirit of typical figures, and guide employees to learn the advanced model and catch up with the advanced around them, forming a strong atmosphere of being positive and learning from others. In addition, enterprises need to pay close attention to the realization of employees' interests. To maintain the synchronous growth of production and operation benefits and the interest level of employees, enterprises leaders are expected to organically combine the immediate interests and long-term interests of employees.

\section{CONCLUSION}

Humanistic theory provides important theoretical support for the high-quality development of state-owned enterprises in the new era. State-owned enterprises should fully realize the value and significance of humanistic theory, practice the humanistic management concept, and contribute to the realization of organizational goals and the all-round development of employees.

\section{REFERENCES}

[1] H.X. Geng. The strategy of humanistic management innovation of power enterprises in the new era $[\mathrm{J}]$. enterprise reform and management, 2017(21):91-92.

[2] G.L. Chen. People-oriented management: the application of Marxist humanism in contemporary enterprise management [D]. Xiangtan University, 2014

[3] J. Lu. Philosophical reflection on people-oriented management of modern enterprises [D]. Capital Normal University, 2011.

[4] T. Wu. Exploring the construction and training countermeasures of scientific research talents in state-owned enterprises-based on humanistic psychology $[\mathrm{J}]$. East China Science and Technology, 2021(04):68-71. 
[5] X.H. Tan. Enlightenment of Marxism on modern enterprise management [J]. Legal System and Society, 2019(24):234-235.

[6] Chris Laszlo. Strengthening Humanistic Management[J]. Humanistic Management Journal, 2019,4(1). 